\title{
ERRATA
}

\section{Listeria ivanovii sp. nov.}

HEINZ P. R. SEELIGER, JOCELYNE ROCOURT, ANGELIKA SCHRETTENBRUNNER, PATRICK A. D. GRIMONT, AND DOROTHY JONES

Institut für Hygiene und Mikrobiologie, D-8700 Würzburg. German Federal Republic; Unité d'Ecologie Bactérienne, and Unité des Entérobactéries, Unité INSERM 199, Institut Pasteur, F-75724 Paris Cedex 15, France; and Department of Microbiology, School of Medicine and School of Biological Sciences, University of Leicester, Leicester LEI 7RH, England

Volume 34 , no. 3 , p. 336, column 1, line 13: "of" should read "or."

\section{Saccharothrix: a New Genus of the Actinomycetales Related to Nocardiopsis D. P. LABEDA, R. T. TESTA, M. P. LECHEVALIER, AND H. A. LECHEVALIER}

Medical Research Division, American Cyanamid Company, Pearl River, New York 10965, and Waksman Institute of Microbiology, Rutgers, The State University, New Brunswick, New Jersey 08903

Volume 34, no. 4, p. 426 through 431: "ATCC 31947" should read "ATCC 31497." 